\title{
ABSOLUTE AND RELATIVE RESOURCES AS DETERMINANTS OF INTERNATIONAL ACQUISITIONS
}

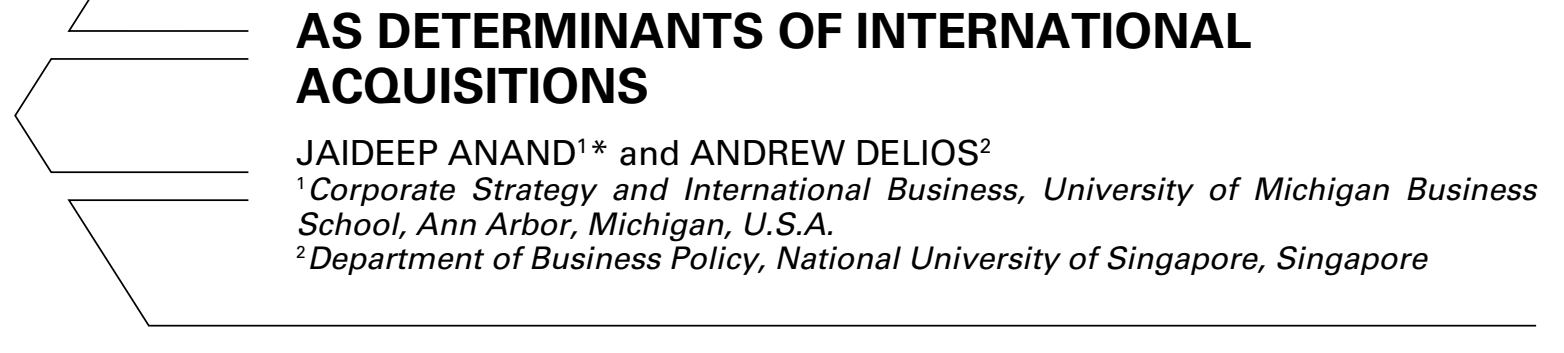

\begin{abstract}
Although it is established that firms sometimes expand abroad to augment their capabilities, previous studies have generally focused on technological determinants of foreign expansion. We analyze capability-seeking aspects of foreign direct investment by examining the relationship between upstream (technological) and downstream (marketing) capabilities and the choice between acquisition and greenfield modes of international entry. In analyzing 2175 entries by British, German, and Japanese investors into the United States, we find that for downstream capabilities, which tend not to be geographically fungible, the absolute level of capabilities in the entered industry explains the mode choice. However, for upstream capabilities, which tend to be geographically fungible, the acquisition motive stems from a relative capability differential between host and home country firms. These results have implications for the concept of fungibility in the resource-based view of the firm as well as for the literature on sourcing of resident assets by foreign firms, which has thus far ignored issues of entry mode and downstream assets. Copyright ( 2002 John Wiley \& Sons, Ltd.
\end{abstract}

Since the early 1990s, there has been an understanding that foreign direct investment (FDI) not only exploits (Morck and Yeung, 1991) but also augments a firm's existing capabilities (Caves, 1996). The latter, the augmentation aspect of foreign entry, has been the focus of recent empirical studies on FDI. These studies have centered on issues of 'reverse internalization' (Eun, Kolodny, and Scheraga, 1996) or 'asset-seeking FDI' (Chung, 2001; Tsurumi, 1976; Yoshida, 1987; Wesson, 1993; Zahra and Hitt, 2000; Gupta and Govindarajan, 2000). This research has provided some insight into the phenomenon of asset-seeking investments as multinationals seek to enhance existing capabilities, but overall the evidence is ambiguous. Sector-specific studies have shown some evidence of the asset-seeking motive (Shan

Key words: acquisition; entry mode; capabilities; technology; distribution

*Correspondence to: Jaideep Anand, Corporate Strategy and International Business, University of Michigan Business School, 701 Tappan Street, Ann Arbor, MI 48109-1234, U.S.A. and Song, 1997); however, empirical studies at the macro-level have failed to detect strong evidence of this motive (Kogut and Chang, 1991; Anand and Kogut, 1997). One explanation for this discrepancy is that the sector-specific studies were made in the areas in which asset-seeking behavior was most likely to be observed. A second explanation is that earlier studies have looked at samples of acquisitions to identify the asset-seeking motive. In this empirical study, we have tried to understand these issues and to contribute to the underlying literatures.

Previous studies in the asset-seeking stream have primarily focused empirical attention on upstream capabilities like R\&D activities (see Caves, 1996: 9-11), with less attention given to the role of downstream capabilities, such as advertising and distribution. Yet, when considering the determination of foreign investment strategy, downstream capabilities play a prominent role (Horst, 1974; Caves and Mehra, 1986; Morck and Yeung, 1991; Hennart and Park, 1993) for numerous reasons. 
First, downstream assets are frequently required to complement a firm's intangible technological advantages (Teece, 1986). Second, distribution systems and advertising are pernicious barriers to entry (Bain, 1956; Porter, 1980). Third, existing brands have a limited cross-border transferability (Hennart and Park, 1993) and distribution systems, by their complexity and physical nature, are not internationally mobile (Horst, 1974).

We attempt to resolve some of the discrepancies found in earlier research on the capability augmentation aspects of FDI by focusing on the role host country marketing or downstream capabilities play in the determination of foreign investment strategy. We explore questions germane to capability-seeking FDI by looking at downstream and upstream capabilities and their relationship to the entry mode choice. In formulating our hypotheses and conducting our empirical results, we consider how upstream and downstream capabilities differ along such dimensions as geographic fungibility and localization or location specificity. We then examine the impact that these dimensions have on the choice to enter by acquisition or greenfield.

As we argue, for downstream capabilities, which are not geographically fungible, the absolute level of capabilities in the entered industry is adequate for explaining the mode choice. However, when capabilities are geographically fungible, such as for upstream capabilities, the impetus for acquisitions emerges from a relative differential between host country firms and the entering firm. Although previous literature has cited fungibility as an important aspect of firm capabilities (Wernerfelt, 1984), empirical research has yet to define the properties of fungible capabilities, or the conditions required for exploiting existing capabilities in new businesses. We seek to create such a definition while extending the literature on entry mode choice.

\section{PREVIOUS RESEARCH}

\section{The motive to acquire}

In absolute terms and as a proportion of total FDI, cross-border acquisitions have been increasing rapidly. For example, U.S. Department of Commerce data show that in the 1980s more than half of all the FDI into the U.S. was made in the form of acquisitions, a share which continued to rise in the 1990s. As has been argued in the resource-based and evolutionary perspectives, acquisitions are a mechanism used to exchange capabilities that are otherwise not possible to efficiently redeploy (Capron, Dussuage, and Mitchell, 1998; Seth, 1990; Lubatkin, Schulze, Mainkar and Cotterill, 2001). The exchange concerns both efficient deployment of existing capabilities in the host country, as in a FDI, and the internalization of new capabilities, bundled as a firm (Penrose, 1959; Wernerfelt, 1984).

As is well documented, firms can deploy existing firm-specific capabilities in a host country via FDI (Caves, 1996), yet when making this deployment the new competitive conditions of the host country can place a demand on the firm to reconfigure existing capabilities or acquire new capabilities (Teece, 1982; Caves, 1996; Zaheer, 1995). Internal development is one option for this; however, the rigidity of organizational routines constrains a firm in developing new capabilities in business activities that vary substantially from existing activities (Nelson and Winter, 1982; Teece, 1987). Where there is difficulty in internal development, a firm can meet demands for new capabilities by entering factor markets, or it can enter the market for corporate control and purchase required capabilities bundled in a firm (Wernerfelt, 1984). However, information asymmetry and opportunism inhibit market-mediated resource transactions (Williamson, 1975), and the cost of using the market increases as resources become more firm-specific and complex (Chi, 1994). Hence, if a firm faces capability demands on foreign entry, and the capabilities are subject to market failure, acquisitions permit the firm to efficiently obtain required capabilities (Teece, 1987; Mitchell, 1994). As summarized by Wilson (1980: 63), 'companies without significant foreign experience may find it necessary to buy existing firms for the purpose of acquiring the capability of dealing with the local environment.'

The flip side of this argument is firms that possess strong capabilities do not have an incentive to acquire (Hennart and Park, 1993). In such cases, there is little value in paying a premium for a foreign target (Doukas, 1995; Markides and Ittner, 1994), especially when a firm possesses the relevant capabilities. Further, these capabilities may be easier to exploit by a greenfield entry than by the acquisition of a firm that can be riddled with organizational inertia (Barkema and Vermeulen, 1998). Greenfield investments also offer 
the investor greater flexibility in the location of plants, decisions about capital outlays, and the design of management systems (Yoshida, 1987).

\section{Upstream assets and entry mode}

In studies of FDI, a robust finding has been that technological capabilities, as embodied in the intangible assets of the investing firm, provide it with competitive advantages over local rivals in the foreign environment (Caves, 1971; Dunning, 1973). Empirical research in this area has typically focused on investments made by U.S. firms in the postwar era, or those made by European firms in their colonies and former colonies (see Dunning, 1993, for a review), in which the foreign investment served as a mechanism for exploiting a firm's technology in international markets. More recently, however, global competition has become less asymmetric, and firms from a wider number of countries have been competing for global dominance. Part of this competition is to acquire the most advanced technology in a firm's field. Firms make investments not only to access markets, but also to tap into locally resident technology. Since technology is intrinsically fungible across borders, firms seek worldwide revenues from technology developed in spatially bound locations. While firms in global industries need to seek capabilities by locating and conducting technological and other important activities outside the home country, the difficulty of developing host country resident capabilities in subsidiaries (Birkinshaw and Hood, 1998) suggests that even within globalizing industries a firm's capabilities and advantages tend to reflect home country expertise.

The research stream exploring capability-seeking behavior differs from the focus on intangible assets as drivers of foreign investment. It concerns the geographical 'pull' of regions (countries) as an attraction for foreign investment (Anand and Kogut, 1997). Countries differ in their asset endowments and advantages for two sets of related reasons: (1) externalities (shared by all firms) emerging from variation in factor prices and differences in institutional environments and linkages between various societal and economic institutions (Freeman, 1987); and (2) the historical accumulation of capabilities at the firm level (Nelson and Winter, 1982), which, in turn, may not be independent of location (Kogut, 1991). Empirical studies on this topic suggest that ownership

Copyright (c) 2002 John Wiley \& Sons, Ltd. advantages are related to geography. For example, Dunning (1990: 29) concludes that 'in high valueadded activities of multinational companies, the main country specific locational determinants have shifted to reflect the innovatory and entrepreneurial dynamism of the recipient economy.' These assets can be complementary to existing ones and permit an investing firm to efficiently exploit and enhance existing competitive advantages.

On one hand, empirical evidence from industrylevel studies of the motive to access locationspecific knowledge is mixed. Kogut and Chang (1991) and Anand and Kogut (1997), who used aggregate data to analyze interindustry variance, found that technologically intensive industries attracted a disproportionate share of FDI; however, the relative technological advantage of the host country did not explain the distribution of FDI among industries. On the other hand, recent sectorspecific studies on biotech and semiconductor industries report clear evidence of the technology acquisition motive. For example, Shan and Song (1997) found that the probability of U.S. biotech labs to be acquired by foreign firms increased with the number of patents held by the biotech lab.

One simple explanation for the discrepancy between studies is that the interindustry variance is not explained by relative U.S. technological advantages because a spectrum of motives are found within each industry. Single-industry studies that focus on firms' relative advantages uncover intraindustry variance. Technology sourcing is visible only at the intraindustry level, with the most attractive firms within an industry most likely to be acquired. This variance is lost when industries are pooled. Yet, important for our explanation of entry modes, by focusing on firm-specific advantages, these single industry studies were, by definition, limited to the analysis of acquisitions of existing host country firms. The greenfield entry mode was ignored. Consequently, these studies were biased towards support of the technologysourcing motive.

Indirectly, the results of these studies collectively point to the importance of entry mode. Kogut and Chang (1991) reported that technology acquisition by Japanese firms occurred via joint ventures. Frost (1998) observed a lower rate of local patent citations by greenfield foreign entries than by acquired firms. Hence, we expect that the choice of entry mode will be driven in part by the relative technological advantages of home and host 
countries. When the host country has a relative advantage, foreign firms are likely to use acquisitions for entry. When the home country has a relative technological advantage, a firm will exploit it abroad by establishing greenfield operations.

This explanation is consistent with recent theoretical advances. Acquisitions enable firms to tap into existing external local networks (Jaffee, Trachtenberg, and Henderson, 1993), and to capture internal routines (Nelson and Winter, 1982) and local 'organizing principles' (Kogut, 1991). However, greenfield entry necessitates that required capabilities are obtained in disembodied form thus putting the firm at a disadvantage in capturing tacit resources and knowledge (Capron et al., 1998). Conversely, if a foreign firm has a relative technological advantage, it need not pay a premium for an acquisition. Hence:

Hypothesis 1: The higher the relative technological intensity of the host country in the entered industry, the more likely entry is by acquisition. Conversely, the higher the relative technological intensity of the home country in the entered industry, the more likely entry is by the greenfield mode.

\section{Downstream assets and entry mode}

Downstream or marketing capabilities have been acknowledged as a critical set of capabilities in a firm's overall portfolio (Teece, 1987; Kapferer, 1992; Day, 1994; Hunt and Morgan, 1995). For FDI, casual and anecdotal observations from the popular press reinforce the importance of downstream assets as a motivation for cross-border acquisitions (Go, Choi, and Chan, 1996; Ellert, Killing, and Hyde, 1997) as these accounts suggest that acquisitions permit an investing firm to access foreign markets through the provision of local assets like salesforce and brands. Other observations are consistent with the supposition that acquisitions can be used for obtaining the downstream capabilities of local firms. For instance, Hennart and Park (1993: 1056) note, '[foreign] investors require complementary inputs which can be more cheaply acquired bundled in a going concern than in disembodied form on the market'. In this context, complementary inputs are those capabilities required to support a firm's intangible technological asset advantages (Teece, 1986). Because R\&D and manufacturing have complex links to branding and distribution (Chi, 1994), a firm must control marketing-related activities to stem opportunistic behavior that can occur when these functions are contracted to domestic firms (Williamson, 1985). This is consistent with empirical observations that foreign entrants tend to find domestic distributors inefficient (Yamawaki, 1991), and foreign manufacturers that invest in local distribution are more successful (Bergsten, Horst, and Moran, 1978).

When devoid of local marketing capabilities, multinational firms have several choices for market entry. For one, a firm can enter using marketing arrangements with local firms (Chen and Hennart, 1995). However, these arrangements risk breeding future competition with local firms, and an entering firm would generally prefer to have tighter control over marketing operations. A second option, building marketing capabilities from scratch, poses other challenges: such investment in a new environment is risky and the returns may be visible only after an extended period during which rivals are able to establish dominant positions. Also, any purchase of inputs is subject to transactional problems, while hiring local managers to build these capabilities is difficult due to the firm-specific nature and uncertain imitability of capabilities (Lippman and Rumelt, 1982). Given the inseparability of capabilities from owners, the acquisition of capabilities by the purchase of local firms remains a dominant choice (Chen and Zeng, 1996).

\section{Brands}

Brands are well recognized as a crucial firmspecific capital resource (Wernerfelt, 1984; Dierickx and Cool, 1989; Amit and Schoemaker, 1993) and are seen as critical to a firm's success in its markets (Kapferer, 1992; Shocker, Srivastava, and Reukert, 1994). Srivastava, Shervani, and Fahey (1998) note that intangible marketing-based assets like brands can be leveraged to reduce costs or increase margins. Further, brands are rare, difficult to imitate, fungible and sticky resources, that require long time horizons to build (Reddy, Holak, and Bhat, 1994; Bergen, Dutta, and Shugan, 1996). The process of building a brand requires cumulative investments in advertising and marketing (Rossiter and Percy, 1997), which leads to awareness as well as positive associations by consumers. This building process also involves interactions with consumers. Wernerfelt (1985) has shown that 
consumers switch between brands only reluctantly due to investments made by consumers in building user skills. Because of the time-consuming nature of brand building, existing brands can be difficult to transfer to new international markets.

Even with the difficulty in transfering brands internationally, such transfer does occur, albeit infrequently. Some prominent global brands are well known to foreign consumers even though familiarity with the product itself (e.g., Mercedes, Levis, and Coke) may be lacking (Owen, 1993). The reputation of hotel chains spreads as travelers cross borders. Consequently, it is not rare to see hotel chains with wide geographic coverage (Dunning and McQueen, 1981). While crossborder brand transfers do occur, such transfers are slow, rare, and generally occur only for prominent brands. In fact, high levels of advertising intensity in the host country can act as an entry barrier and deter foreign entry (Kessides, 1986). For example, entry in the United States is difficult in advertisingintensive industries because U.S. firms tend to be highly competitive in these industries (Lall and Siddharthan, 1982). Hence, even among prominent brands, foreign penetration is rare: just 6 percent of the most popular brands in the United States are owned by foreign firms (Owen, 1993).

The difficulty in transferring brand capital from one market to another enhances the viability of using local brands. However, arm's-length transactions in the market for brands suffer from transaction cost problems (Caves, 1996). Also, pricing is problematic because it is difficult to estimate the financial value of a brand to a new owner (Kapferer, 1992). Furthermore, effective brand management requires complex interactions within the organization and with consumers, which leads to impediments associated with the transfer of tacit knowledge (Nelson and Winter, 1982). Given these constraints to the cross-border transfer and market-based purchase of existing brands, the motivation to capture brands in new markets often leads to an acquisition (Capron and Hulland, 1999). Consequently, we expect acquisitions to be more common in advertising-intensive industries.

Hypothesis 2: The greater the advertising intensity in the entered industry, the greater the probability the mode of foreign entry will be by acquisition.

\section{Salesforce}

Existing marketing relationships are a valuable firm-specific resource, and are perceived to be essential to gaining firm-specific competitive advantage (Dwyer, Schurr, and Oh, 1987; Webster, 1992). Further, distribution and salesforces are particularly difficult to build and only a small number of firms have successfully leveraged these capabilities (Smith and Barclay, 1997). This difficulty arises from the complexity of social organizations, processes, and systems required to support and sustain the demanding relationships between buyers and sellers (Capron and Hulland, 1999). Much time is required to build and sustain salesforce systems because they are enmeshed in intricate social networks that require tailoring to the product and consumer. This tailoring leads to the creation of highly specific assets, the challenges of managing which are compounded by difficulties in performance evaluation (Anderson and Coughlan, 1987; Majumdar and Ramaswamy, 1994).

At the other end of the salesforce system exist complex links to manufacturing, in which the organizational component of this aspect of the system is firm-specific (Chi, 1994). This specificity inhibits market-based exchange of salesforce systems. Further, rapid internal development of distribution and salesforce systems is restricted by the 'time compression diseconomies' encountered in the building of relationships and the development of familiarity with location-specific business practices (Dierickx and Cool, 1989). Hence, for a foreign entrant, the build option for a salesforce system is one that is difficult to pursue.

The same factors that make a salesforce system difficult to build from scratch also constrain its cross-border transferability. Distribution systems tend not to be fungible across borders because of their physical nature, and the specific intangible component found in the relationships between producer and consumer and in the relationships between the marketing and production functions. Given its lack of fungibility, a strong domestic salesforce system is not sufficient as an impetus for internationalization (Horst, 1974). As a consequence, when entering a foreign market, a firm must develop or acquire a new salesforce or distribution system. However, as argued above, these systems are difficult to obtain in intermediate markets, and time-consuming to build. Therefore, the 
most efficacious option for foreign entry is often an acquisition.

Hypothesis 3: The more intensively salesforce is used in the entered industry, the greater the probability the mode of foreign entry will be by acquisition.

\section{RESEARCH METHODOLOGY}

\section{Data description}

We tested our three hypotheses using a sample of entries made into the United States in the 1974-91 period. Entries into the United States were collected from compilations of foreign entry by the International Trade Administration at the Department of Commerce, published annually in Foreign Direct Investment in the United States. We first selected all entries made by the major investing countries into the United States during the time period for the study: 1974-91. The major investing countries were Japan (4160 entries), the U.K. (2778 entries), Canada (2316 entries), Germany (1540 entries), France (924 entries), the Netherlands (745 entries), and Switzerland (556 entries). We expect a substantial part of the Canadian FDI to be made by the Canadian subsidiaries of U.S. firms. This complicates the identification of the capability-sourcing motive, because the base for the parent firm of the Canadian subsidiary is in the United States, suggesting that it has already developed capabilities suitable to the American context. Further, Canada's locational contiguity to the United States and the Free Trade agreement raise distinct issues that merit their own analysis.

The Dutch and Swiss investments were dominated by a small number of firms (Philips, Unilever and Shell in the Netherlands, and Nestlé in Switzerland), so the R\&D data were not released for enough sectors to allow testing. Initially, we included the French data, but the highly aggregate nature of the concentration data from French sources meant that the results, while in line with the predicted relationships, were poor. Consequently, we removed the French data from the analysis. This left three countries, Japan, Germany and the United Kingdom, which accounted for 65 percent of all investments in the United States by major investing countries.

The next sample selection criterion was the mode of entry. The International Trade Administration lists six categories of foreign direct investment: acquisitions/mergers, new plants, joint ventures, equity increases, real estate purchases and all other (branches, agencies, representative offices, stores, outlets, warehouses, and unidentified transactions). In our sample, acquisitions conformed to the acquisition and merger category. We coded entries identified by the International Trade Administration as new plants as greenfields. Although joint ventures (JVs) represent an alternative source of learning for new capabilities (Inkpen and Beamish, 1997), JVs accounted for less than 10 percent of the entries made by firms from these three countries. Hence, all other forms of entry were not included in the sample.

After these sample selection procedures, and the elimination of cases with missing values, the sample comprised 2175 entries, counted at the 4-digit SIC level, made by firms from Germany, Japan, and the United Kingdom into the United States during the 1974-1991 period, inclusive. Means and correlations of all variables are provided in the Appendix. Table 1 summarizes the hypotheses and definitions of all variables.

\section{Independent and control variables}

We constructed three measures of the brand and salesforce demands of the entered industries. Two measures were constructed from expenditure data, with the third computed from employment data. We used industry-level data because the hypotheses concerned the capabilities a foreign firm needs to acquire to compete as a typical firm within the U.S. industry that it entered.

We utilized advertising expenses and sales expenses, respectively, as measures of brand equity and the intensity of distribution in the entered industries. We obtained data for constructing these measures (and the R\&D measure) from the Federal Trade Commission (FTC) Line of Business Report for 1977 for the United States. The FTC report defines advertising as media advertising expenses. Sales expenses are defined as other selling expenses. We used salesforce information as the second measure of the intensity of distribution. We developed this measure from employment information compiled in a 50,000-firm survey of the employment practices of U.S. firms conducted by the Bureau of Labor Statistics, U.S. Department of Labor. This survey collected information 
Table 1. Summary of hypotheses and variable definitions

\begin{tabular}{|c|c|c|}
\hline Hypotheses & Measures & $\begin{array}{l}\text { Relationship } \\
\text { to acquisition } \\
\text { frequency }\end{array}$ \\
\hline H1: Technological capabilities & $\begin{array}{l}\text { 1. Difference in R\&D expenditure intensities between } \\
\text { host and home countries (host less home) } \\
\text { 2. Dummy variable that takes a value of one if } R \& D \\
\text { expenditure intensities in the host country are greater } \\
\text { than those in the home country }\end{array}$ & $(+)$ \\
\hline H2: Brands & $\begin{array}{l}\text { 1. Advertising expenses as percent of sales (host } \\
\text { country) }\end{array}$ & $(+)$ \\
\hline H3: Salesforce & $\begin{array}{l}\text { 1. Selling expenses as percent of sales (host country) } \\
\text { 2. Salesforce employment as percent of overall } \\
\text { employment (host country) }\end{array}$ & $(+)$ \\
\hline \multicolumn{3}{|l|}{ Dependent variable } \\
\hline Proportion of entries by acquisition & $\begin{array}{l}\text { Binary responses for individual entries (acquisition }=1 \text {, } \\
\text { greenfield }=0 \text { ) are grouped by the } 4 \text {-digit SIC } \\
\text { industry-home country-year of entry, to form a } \\
\text { group-level proportion of entry by acquisition }\end{array}$ & \\
\hline \multicolumn{3}{|l|}{ Control variables } \\
\hline Technological intensity & $\begin{array}{l}\text { 1. } R \& D \text { expenditures as percent of sales in host country } \\
\text { 2. } R \& D \text { expenditure as percent of sales in home country }\end{array}$ & - \\
\hline Technological intensity of industry & $\begin{array}{l}\text { Sum of R\&D expenditure intensities in home and host } \\
\text { countries (host R\&D plus home R\&D) }\end{array}$ & - \\
\hline Industry size & Average annual value of shipments $(1975-85)$ & $(-)$ \\
\hline Industry growth rate & Growth in sales (average $\%$ increase over previous year) & $(+)$ \\
\hline U.S. concentration & 4-firm concentration ratio (\%) 1972, 1977, 1982 & $(+)$ \\
\hline Home country concentration & 4-firm concentration ratio (\%) 1982 & - \\
\hline Germany dummy & Country dummy $($ Germany $=1)$ & $(+)$ \\
\hline Japan dummy & Country dummy $($ Japan $=1)$ & $(+)$ \\
\hline Fixed effects for industry & SIC 2-digit industry dummy variables & \\
\hline Fixed effects for time & Year of entry dummy variables (1974 to 1991) & \\
\hline
\end{tabular}

on the number of employees in specific employment categories. The U.S. Department of Labor defined one employment category as salesforce (persons selling goods and services and others directly related to sales). Our salesforce measure was the number of salesforce employees in an industry divided by the total number of employees in that industry.

To capture the effect of technology in the home and host countries, we used the sum and difference of $R \& D$ intensities ( $R \& D$ expenditures divided by industry size) within industries in the home and host countries. The former captures the overall technological intensity of a sector, whereas the latter captures the relative position of the two countries. Given the high correlation between R\&D intensities across countries $(r=0.70)$, we cannot use these measures without this transformation. We gathered the R\&D measures for Japan, Germany, and the United Kingdom from unpublished data collected by the OECD, as carried in the Business
Enterprise and Research Development (ANBERD) dataset. The data were reported annually for the 1973-90 period.

We used several controls to account for the effects of industry, time, and the country of origin of the investment. For country-level effects, we coded one dummy variable for German entries and one for Japanese entries. For industry-level variables we used standard proxies for market attractiveness and entry barriers: home and host country industry concentration, industry shipments and shipment growth as available from unpublished reports of the U.S. Department of Commerce. The U.S. concentration data were available for the years 1972, 1977, and 1982. We matched these data to the entries made in the most proximate years. All industry measures were made at the 3- or 4-digit SIC levels. We obtained European concentration data from EU sources, and Japanese concentration data from the Fair Trade Commission of Japan. 


\section{Research design ${ }^{1}$}

To test the three hypotheses, we use a design that permits investigation of the effect of cross-industry variance in upstream and downstream capabilities on the propensity to enter by greenfield or acquisition plant. Our variable of interest is a binary response-acquisition or greenfield-for each individual entry. However, our independent variables are at the industry level. To avoid oversampling, which would be the case if we used a discrete choice model in which each individual entry counted as one observation, we used a grouped data approach, and analyzed the proportions of acquisitions within a group.

Grouped data can be obtained by observing the responses of individual entrants, each of which belong to the same category (Greene, 1997: 894). We grouped individual responses by the 4-digit SIC industry of entry, year of entry, and home country of the entrant. This grouping creates an industry-level dependent variable, which is the proportion of investments made by acquisition in unique industry-country-year categories. The appropriate statistical technique for estimation is a grouped probit model with a logit distribution for the dependent variable. The estimation and interpretation of coefficients in a grouped probit model is similar to an individual response probit model. The one adjustment that needs to be made is to rescore proportions that equal 0 or 1 as 0.001 and 0.999 , respectively, to avoid problems in the maximum likelihood estimation that can occur when proportions equal 0 or 1 (Greene, 1997: 896).

This combination procedure for our 2175 entries resulted in 1508 discrete industry-country-year groups. The largest number of entries in a group was 41-Japan's entries into automotives in 1990, 97.6 percent of which were by greenfield. Seventysix percent of groups had one observation. We ran a grouped probit model with fixed effects for entry year as well as SIC 2-digit fixed effects, both of which were significant as a group in all models reviewed below.

\footnotetext{
${ }^{1}$ We initially implemented statistical testing using a binary choice model in which each entry counted as an observation. This form of modeling led to deflated standard errors and inflated $t$-statistics for several coefficient estimates. Following the expert assistance of an anonymous reviewer, we implemented a grouped probit model, which is a qualitative response model estimated by many statistical packages such as LIMDEP and SAS.
}

\section{RESULTS}

In Table 2, we report the results of eight specifications. As indicated by the chi-square statistics, each of the models was a significant and substantive predictor of the entry mode choice. The first six models in Table 2 differed in the independent variables that were included in the model. In all models, positive signs on a coefficient indicate a greater propensity to enter by acquisition.

Model 1 shows the effects for the control variables, while accounting for industry fixed effects and the fixed effects for the time of entry. The addition of the control variables marked a significant improvement over the fixed effects only model. In Model 1, the coefficients for home concentration, the country dummies, and the two groups of fixed effects were significant at the 0.001 level. Industry size, as measured by shipments, industry growth, and host concentration, was not significant in any of the six models. If we excluded the fixed effects for industry, industry size was significant at the 0.05 level, and had its expected negative sign.

Model 2 initiates the hypothesis-testing portion of the analysis. Hypothesis 1 predicts that the relative level of technology drives the choice between acquisition and greenfield. We test this hypothesis, while also testing for alternative explanations. We first examine the effect of host country R\&D on the choice to acquire. As shown in Model 2, host country R\&D by itself is not significant and its addition to the basic model does not improve model fit. This is evidence that the absolute level of R\&D spending in the host country does not affect the entry mode choice. A similar test (not shown) of home country R\&D shows that the inter-sectoral levels of home country spending on $R \& D$ did not affect the entry mode choice. This evidence is consistent with the thrust of Hypothesis 1; however, independent of other tests it does not provide confirmation.

Model 3 adds the R\&D sum and difference variables to the basic model. The R\&D sum variable acts as a test of the effect of absolute expenditures on the build vs. buy decision, while R\&D difference tests the relative expenditure effect. The positive sign on the R\&D difference dummy variable $(p<0.05)$ supports Hypothesis 1 , while $\mathrm{R} \& \mathrm{D}$ sum is not significant. This result shows that acquisitions took place in sectors in which the home country trailed the host country in terms of technology. 


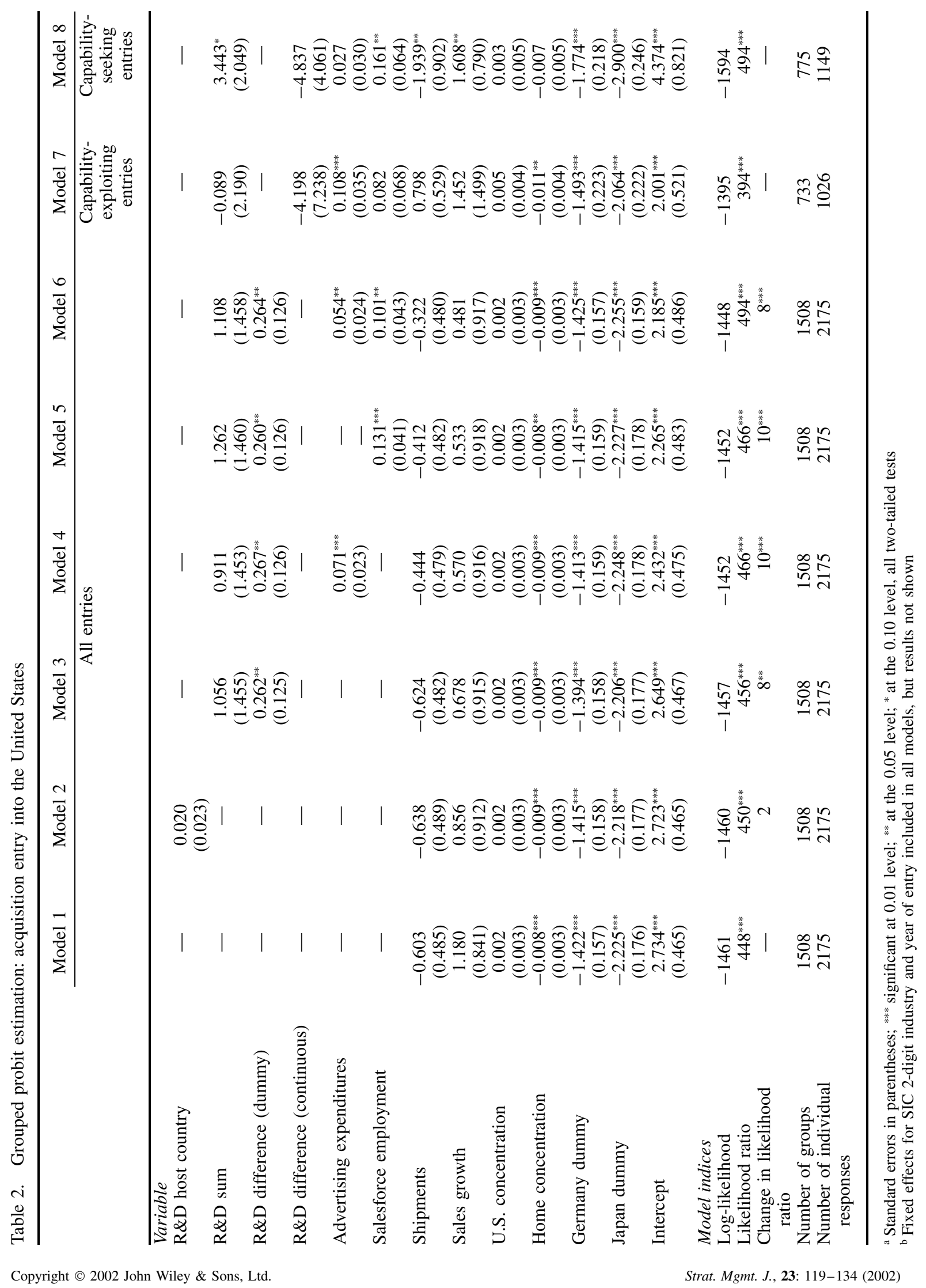


Models 4 and 5 look at the effect of the marketing capability variables in isolation as well as testing the effect of the R\&D sum and R\&D difference variables. The two downstream capabilities variables shown in the table had similar effects. The coefficients on the advertising intensity and the salesforce employment intensity measure were significant $(p<0.001)$ and positive. A test of the sales expenditure variable (not shown) likewise revealed highly significant and positive effects. Furthermore, as indicated by the incremental chisquare statistics, the addition of these variables improved the overall fit of the model compared to a model without any downstream capabilities terms.

Model 6 presents a further refinement of the modeling procedure through the addition of the salesforce employment measure to the specification reported in Model 4. Influence and VIF statistics indicated this model had no collinearity problems, and the coefficients on the advertising expenditure and salesforce measures were significant and signed as predicted. Further, the addition of the salesforce employment term significantly improved the model's fit compared to the advertising expenditure only model (Model 4). We note that a model with both advertising and sales expenditures was not interpretable because of the high collinearity $(r=0.79)$ between the two expenditure terms.

Model 6 also displays results common to Models $2-5$ with respect to the control variables. The size, growth rate, and home concentration of the sector in which an investment was made did not affect the build or buy choice. Further, acquisitions were less frequent when made by firms from more highly concentrated industries in the investor's home country. Finally, we observed that firms from the United Kingdom had a markedly higher propensity to acquire than firms from Germany or Japan. The preference for Japanese firms to enter by greenfield is well noted in the extant literature (Anand and Kogut, 1997; Beamish, Delios, and Lecraw, 1997). Similarly, British firms' preference for acquisitions has been noted (Kogut and Singh, 1988, Anand and Kogut, 1997). These differences in propensities by home nation may be attributed to market-driven corporate governance systems and active markets for corporate control in Anglo-Saxon economies and, consequently, a greater reliance on acquisitions in domestic and international settings. Kogut and Singh (1988) have also speculated on 'cultural' drivers for entry mode.

\section{Capability-seeking and capability-exploiting entries $^{2}$}

We next developed two models, also found in Table 2, to further examine the hypotheses using subsamples of our data. The subsamples isolated the effects of asset-seeking and asset exploitation behavior. We conducted this test by dividing the sample into industries in which foreign firms had a technological edge (capability or asset exploitation) compared to U.S. firms, and into industries in which foreign firms had a technological disadvantage (capability or asset seeking). We isolated firms into these categories using the R\&D difference variable. If the variable was positive, that is the U.S. technology was greater than that of the home country, we assumed asset-seeking behavior. If the $R \& D$ difference was negative, we assumed asset exploitation behavior.

Model 7 in Table 2 displays the results for the group of asset-exploiting firms. For this sample of firms, the absolute and relative levels of $R \& D$ were not significant, nor was the salesforce measure. Among the capabilities variables, only advertising was significant $(p<0.01)$, and signed in the predicted direction. The same test using the sample of asset-seeking firms shows a markedly different pattern in the coefficients (Model 8). The advertising measure tended to insignificance in this model, while one upstream measure, R\&D sum $(p<0.10)$, was significant as was the salesforce measure $(p<0.05)$. Notably, the sign on the $\mathrm{R} \& \mathrm{D}$ sum measure was positive. Together, this set of results indicates that asset-seeking firms were more likely to undertake acquisitions for technology than asset-exploiting firms (the positive sign on the R\&D difference dummy in Model 6), with the propensity to acquire for firms within the assetseeking group greater when technology was more important within an industry.

We also made additional explorations of the capability-seeking and exploitation aspects of Hypotheses 2 and 3. We explored these downstream hypotheses further by examining whether firms in consumer product industries, in which the exploitation of brands across countries would be most

\footnotetext{
${ }^{2}$ We thank an anonymous reviewer for suggesting this set of analyses.
} 
likely to occur, had the same acquisition propensity as firms in other industries. We constructed two measures to mark whether a firm was in a consumer products industry or not. The first measure was based on the consumer and producer industries defined by Kohn (1988). The second measure was based on Porter's (1976) classification of convenience and nonconvenience goods. Firms competing in convenience goods tend to be associated with high advertising expenditures because of the need to develop a strong brand name to support product differentiation. Using these two measures, we found that firms entering consumer goods industries did not have a greater or lesser propensity to acquire than firms not entering consumer goods industries. Further, we found no difference in the determinants of acquisition within subsamples of consumer and producer goods industries, suggesting that foreign investors generally were not extending home country brands into the United States in consumer goods industries.

\section{DISCUSSION}

The two sets of models provided support for the general framework for this study. Upstream and downstream capabilities were significant determinants of the choice to enter a foreign market by acquisition or greenfield. As shown in the models, foreign investors tended to acquire domestic firms when the sector in which the foreign firm was investing was technically superior to the same sector in the home country of the investing firm. Otherwise, greenfield entries were made. This result is interesting in light of the results of previous empirical studies. Previous interindustry studies have found that the overall technological intensity of a sector explained the relative level of investment in an industry; however, we find that the relative technological advantage (difference in R\&D intensities) is a significant determinant of entry mode choice. This entry mode behavior conforms with a technology-sourcing motive to foreign investment and to acquisitions. Further, when considering the previously mentioned discrepancy between broad and sector-specific studies, we conclude that the capability-seeking argument may not be limited to specific sectors, but that capabilityseeking investment generally takes the form of acquisitions.
We attribute the use of acquisition for foreign entry to the characteristics of capabilities sought in foreign investment. For example, a technologysourcing motive leads a firm to invest in international markets with an eye to improving its competitiveness by locating in geographically dispersed regions of technological innovation. Because technological assets tend to be tacit and firm-specific, interfirm transfer is subject to inefficiencies (Capron et al., 1998). A market interface fails to negotiate efficiently the transfer of technological assets. The most efficient route for this is an internalized exchange-for example, an intrafirm transfer between a parent and subsidiary. Given the failures for a marketmediated exchange of technological assets, firms can obtain desired technological capabilities efficiently by acquiring domestic incumbents. The choice between exploitation of existing capabilities and exploration of new technologies corresponds to the choice between using greenfield and acquisition modes, and is strongly influenced by the relative technological position of the home and host country environments.

While a relatively superior technological position of the host country encourages acquisitions, there is not a greater propensity to acquire as the magnitude of difference between the host and home country increases. Rather, in situations in which host country incumbents are in a superior technological position, the propensity to acquire does not change given a greater difference between the technological positions of host and home country firms. Meanwhile, within sectors in which firms are making capability-seeking investments, the propensity to acquire is influenced by the absolute technological position of the sector. This result is suggestive of a strong technological rivalry component to foreign investment in sectors in which technology is important, and in which foreign firms trail their U.S. counterparts.

While upstream, or technological, capabilities carry the characteristic of geographic or crossborder fungibility, we suggest that downstream assets are not fungible to the same degree. Brands and salesforces tend to be more location-bound than technological capabilities. Part of this is driven by the greater degree of interaction with the consumer among the marketing functions, as compared to technical or operational functions. Also, part of this is driven by the path-dependent development of downstream capabilities. The effect of a

Strat. Mgmt. J., 23: 119-134 (2002) 
lack of cross-border fungibility of marketing capabilities, even within a firm, means that a firm undertaking a foreign investment must secure these capabilities when investing, or attempt to develop new capabilities after making the investment.

While the different types of downstream capabilities share the common attribute of a lack of cross-border fungibility, the relative effect of the different types of downstream capabilities on entry mode is not equivalent because of their variance in fungibility. Specifically, compared to salesforces, brands have a greater degree of cross-border fungibility due to their intangible nature. This is reflected in the relatively weaker influence of brands on the propensity to acquire (see Figure 1). To the extent that the acquisition of a new brand cannibalizes opportunities for the deployment of existing brands in the host country, we observe this weaker influence on acquisition activity for brands.

Further to this, brands appear to be a motivation for acquisition only in sectors in which foreign firms are making investments that exploit a relative technological advantage. When the motivation for investment is technology seeking (as in Model

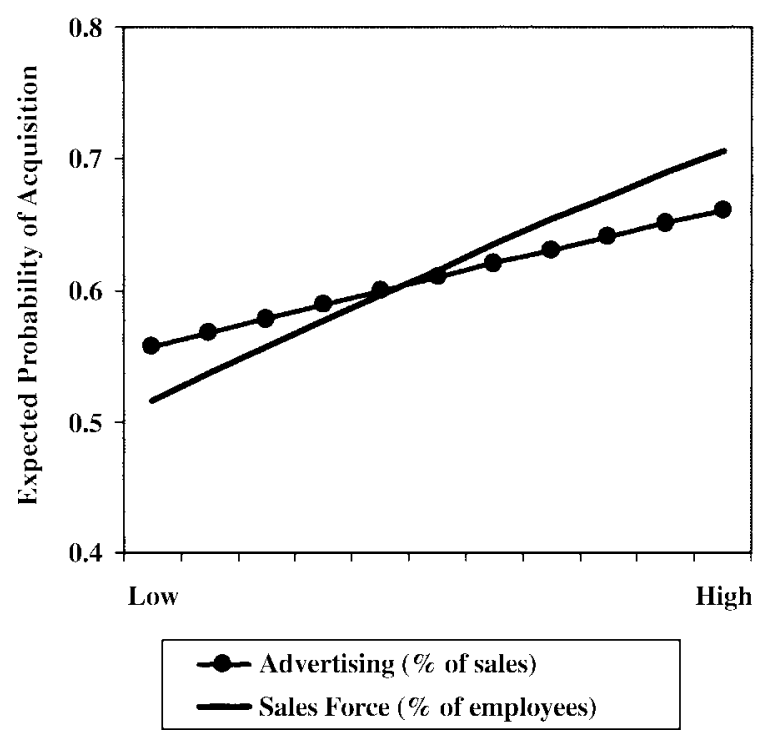

Figure 1. Probability of acquisition entry by Japanese, German and British Firms into the United States $(1974-91)^{*}$

* All independent variables held constant at their mean levels with the exception of advertising and salesforce for the respective plots. Plots based on coefficient estimates from Model 6 in Table 2.

Copyright $(2) 2002$ John Wiley \& Sons, Ltd.
8), the advertising effect is nonexistent. That is, it is not the acquisition of advertising-related assets per se that motivates foreign entry. However, when a firm is making a technological asset-exploiting investment, brands are sought as a complementary asset on foreign entry (Teece, 1986), and an acquisition mode is used to gain that asset. The lack of mobility of the home country brand induces the acquisition, but at the same time the lack of fungibility of downstream assets means that, unlike upstream assets, there is a limited geographic horizon to the application of newly acquired downstream assets. Even so, at least in a large market like the United States, there is a sufficiently large market-related motivation to justify the acquisition of downstream assets. The same motivation might not exist in smaller, more isolated markets such as South Africa or Malaysia.

\section{Limitations and future research}

A primary limitation of this study is that we did not measure capabilities at the firm level, nor did we account for unexplained firm variance in the propensity to acquire. This limitation constrained our ability to test firm-level effects more acutely, particularly the effect of a firm's downstream assets on its propensity to acquire. However, even with the limitations inherent to an industry-level study, we were able to show that the entry mode choice was affected by capability considerations. As the use of an industry-level study is likely to attenuate such firm-level capability effects, we expect that the results we have obtained are likely to be more prominent at more disaggregate levels of analysis.

A second limitation emerges from our assumption that the technological level of a firm's country was reflective, with some variation around the mean, of the general level of a firm's capabilities. However, in industries in which multinational firms increasingly conduct important technological activities outside of the home country, the level of technology in the home country might be a poor reflection of that of the firm. In fact, our results reflect such an effect, as we found that German, Japanese, and U.K.-based firms were making technology-acquisitive investments in the United States. This type of investment, given the time period of our study, 1974-91, was likely part of the movement of industries from domestic competition to global competition. 
Although we could capture an aspect of movement to global competition by identifying capability-seeking investment, we could not explore effects related to an individual firm's trajectories of evolution in international markets. This effect is commonly observed in experience-based studies of foreign entry behavior (e.g., Barkema and Vermeulen, 1998), in which levels of experience act independently and interact to influence entry mode behavior (Delios and Henisz, 2000). An extension to this study involves the exploration of how a firm's international experience influences its capability-seeking behavior as well as its ability to exploit capabilities that had been sought in foreign investments. Part of this examination could also extend the analysis to alternative modes of entry. The proliferation of equity and nonequity alliances implies a strong imperative to study how acquisitions and joint ventures, for example, rival each other as sources of capabilities for foreign investing firms seeking capabilities in foreign markets (Anand and Delios, 1997; Hennart and Reddy, 2000).

Finally, as we have identified that investment from other countries, such as Canada, into the United States, might have differing motivations and mode outcomes, we must note that the empirical portions of our study have generalizability concerns, even though the theoretical framework should apply across host country contexts.

\section{CONCLUSION}

Our empirical results provide support for our arguments about the important role that capabilities occupy as an influence on the choice between acquisition and greenfield entry. The role of downstream capabilities varied by whether a foreign firm was making a capability-seeking or a capability-exploiting investment, but when downstream capabilities were being sought the propensity was to use an acquisition. At a broad level, these results conform to a model of multinational activity that sees technology as being sourced locally but exploited globally, whereas downstream capabilities are sourced and exploited locally. We also hope that these results will, by highlighting the interaction between geography, technology and FDI, help in completing a picture of the relationship between downstream capabilities, FDI, and entry mode.

\section{ACKNOWLEDGEMENTS}

Andrew Delios was at Hong Kong University of Science and Technology during the development of this study. We are grateful to Bruce Kogut for his insights and for some of the data used in this study, and to Jeff Krug, Will Mitchell, two anonymous referees, participants at the Academy of International Business and Academy of Management meetings, and seminar participants at the University of Western Ontario for many useful comments on previous versions of the manuscript. All errors remain ours.

\section{REFERENCES}

Amit R, Schoemaker PJH. 1993. Strategic assets and organizational rent. Strategic Management Journal 14(1): 33-47.

Anand J, Delios A. 1997. Location specificity and the transfer of downstream assets to foreign subsidiaries. Journal of International Business Studies 28: 579-604.

Anand J, Kogut B. 1997. Technological capabilities of countries, firm rivalry and foreign direct investment. Journal of International Business Studies 28: $445-465$.

Anderson E, Coughlan AT. 1987. International market entry and expansion via independent or integrated channels of distribution. Journal of Marketing 51: 71-82.

Bain JS. 1956. Barriers to New Competition. Harvard University Press: Cambridge, MA.

Barkema HG, Vermeulen F. 1998. International expansion through start-up or acquisition: a learning perspective. Academy of Management Journal 41: 7-26.

Beamish PW, Delios A, Lecraw DJ. 1997. Japanese Multinationals in the Global Economy. Edward Elgar: Cheltenham, U.K.

Bergen M, Dutta S, Shugan SM. 1996. Branded variants: a retail perspective. Journal of Marketing Research 33: 9-19.

Bergsten FC, Horst T, Moran TH. 1978. American Multinationals and American Interests. Brookings Institution: Washington, D.C.

Birkinshaw J, Hood N. 1998. Multinational subsidiary evolution: capability and charter change in foreignowned subsidiary companies. Academy of Management Review 23: 773-795.

Capron L, Dussuage P, Mitchell W. 1998. Resource redeployment following horizontal acquisitions in Europe and North America, 1988-92. Strategic Management Journal 19(7): 631-661.

Capron L, Hulland J. 1999. Redeployment of brands, salesforce and general marketing expertise following horizontal acquisitions: a resource based view. Journal of Marketing 63: 41-65. 
Caves RE. 1971. International corporations: the industrial economics of foreign investment. Economica 38: $1-27$.

Caves RE. 1996. Economic Analysis and the Multinational Corporation (2nd edn). Cambridge University Press: Cambridge, U.K.

Caves RE, Mehra SK. 1986. Entry of foreign multinationals into U.S. manufacturing industries. In Competition in Global Industries, Porter ME (ed.). Harvard Business School Press: Boston MA; 449-481.

Chen SF, Hennart JF. 1995. A Testable Theory of the Impact of Private Branding on the Relative Competitiveness of Foreign Versus Domestic Products. Academy of International Business Meeting: Seoul, South Korea.

Chen SF, Zeng M. 1996. Reputation Barriers, Marketing Capabilities, and Japanese Investor's Choice of Entry Strategy into the U.S. Academy of International Business Meeting: Banff, Canada.

Chi T. 1994. Trading in strategic resources: necessary conditions, transaction cost problems, and the choice of exchange structure. Strategic Management Journal 15(4): 271-290.

Chung WC. 2001. Identifying technology transfer in foreign direct investment: influence of industry conditions and investing firm motives. Journal of International Business Studies 32: 211-229.

Day G. 1994. The capabilities of market-driven organizations. Journal of Marketing 58: 37-52.

Delios A, Henisz WJ. 2000. Japanese firms' investment strategies in emerging economies. Academy of Management Journal 43: 305-323.

Dierickx I, Cool K. 1989. Asset stock accumulation and sustainability of competitive advantage. Management Science 35: 1504-1510.

Doukas J. 1995. Overinvestment, Tobin's q and gains from foreign acquisitions. Journal of Banking and Finance 19: 1285-1303.

Dunning JH. 1973. The determinants of international production. Oxford Economic Papers 25: 289-336.

Dunning JH. 1990. The Globalization of Firms and the Competitiveness of Nations. Lund University Press: Lund.

Dunning JH. 1993. Multinational Enterprises and the Global Economy. Addison-Wesley: Wokingham, U.K.

Dunning JH, McQueen N. 1981. The eclectic theory of international production: a case study of the international hotel industry. Managerial and Decision Economics 2: 197-210.

Dwyer FR, Schurr P, Oh S. 1987. Developing buyerseller relationships. Journal of Marketing 51: 11-27.

Ellert JC, Killing JP, Hyde DG. 1997. Nestlé-Rowntree (A). In Business Policy: A Canadian Casebook (4th edn). Crossan MM, Fry JN, Killing JP, White RE (eds). Prentice-Hall: Scarborough, ON; 583-609.

Eun CS, Kolodny R, Scheraga C. 1996. Cross-border acquisitions and shareholder wealth: tests of the synergy and internalization hypothesis. Journal of Banking and Finance 20: 1559-1582.

Freeman C. 1987. Technology, Policy and Economic Performance. Pinter: London, U.K.
Frost T. 1998. The geographic sources of innovation in multinational enterprise: U.S. subsidiaries and host country spillovers, 1975-90. PhD dissertation, MIT: Cambridge, MA.

Go F, Choi T, Chan C. 1996. Four-Seasons Regent: building a global presence in the luxury market. Cornell Hotel and Restaurant Administration Quarterly 37: $58-68$.

Greene WH. 1997. Econometric Analysis (3rd edn). Prentice-Hall: Upper Saddle River, NJ.

Gupta A, Govindarajan V. 2000. Knowledge flows within multinational corporations. Strategic Management Journal 21(4): 473-496.

Hennart JF, Park YR. 1993. Greenfield vs. acquisition: the strategy of Japanese investors in the United States. Management Science 39: 1054-1070.

Hennart JF, Reddy SB. 2000. Digestibility and asymmetric information in the choice between acquisitions and joint ventures: where's the beef? Strategic Management Journal 21(2): 191-193.

Horst T. 1974. At Home Abroad: A Study of the Domestic and Foreign Operations of the American FoodProcessing Industry. Ballinger: Cambridge, MA.

Hunt SD, Morgan RM. 1995. The comparative advantage theory of competition. Journal of Marketing 59: 1-15.

Inkpen AC, Beamish PW. 1997. Knowledge, bargaining power and the instability of joint ventures. Academy of Management Review 22: 177-203.

Jaffee A, Trachtenberg M, Henderson R. 1993. Geographic localization and knowledge spillovers: evidence from patent citations. Quarterly Journal of Economics 108: 577-598.

Kapferer JN. 1992. Strategic Brand Management: New Approaches to Creating and Evaluating Brand Equity. Kogan Page: London, U.K.

Kessides I. 1986. Advertising, sunk costs and barriers to entry. Review of Economics and Statistics 68: 84-95.

Kogut B. 1991. Country capabilities and the permeability of borders. Strategic Management Journal, Summer Special Issue 12: 33-47.

Kogut B, Chang SJ. 1991. Technological capabilities and Japanese direct investment in the United States. Review of Economics and Statistics 73: 401-443.

Kogut B, Singh H. 1988. The effect of national culture on the choice of entry mode. Journal of International Business Studies 19: 411-433.

Kohn TO. 1988. International entrepreneurship: foreign direct investment by small U.S.-based manufacturing firms. DBA thesis, Harvard University. Boston, MA.

Lall S, Siddharthan NS. 1982. The monopolistic advantages of multinationals: lessons from foreign investment in the U.S. Economic Journal 92: 668-683.

Lippman SA, Rumelt RP. 1982. Uncertain imitability: an analysis of interfirm differences in efficiency under competition. Bell Journal of Economics 13: 418-438.

Lubatkin M, Schulze WS, Mainkar A, Cotterill RW. 2001. Ecological investigation of firm effects in horizontal mergers. Strategic Management Journal 22(4): 335-357.

Majumdar SK, Ramaswamy V. 1994. Explaining downstream integration. Managerial and Decision Economics 15: 119-130. 
Markides CC, Ittner CD. 1994. Shareholder benefits from corporate international diversification: evidence from U.S. international acquisitions. Journal of International Business Studies 25(2).

Mitchell W. 1994. The dynamics of evolving markets: the effects of business sales and age on dissolutions and divestitures. Administrative Science Quarterly 39: 575-602.

Morck R, Yeung B. 1991. Why investors value multinationality. Journal of Business 64(2): 165-188.

Nelson RR, Winter SG. 1982. An Evolutionary Theory of Economic Change. Harvard University Press: Cambridge, MA.

Owen S. 1993. The Landor Image Power Survey: a global assessment of brand strength. In Brand Equity and Advertising, Aaker DA, Biel AL (eds). Erlbaum: Hillsdale, NJ; 11-30.

Penrose ET. 1959. The Theory of the Growth of the Firm. Basil Blackwell: Oxford, U.K.

Porter ME. 1976. Interbrand Choice, Strategy, and Bilateral Market Power. Harvard University Press: Cambridge, MA.

Porter ME. 1980. Competitive Strategy. Free Press: New York.

Reddy SK, Holak SL, Bhat S. 1994. To extend or not to extend: success determinants of line extensions. Journal of Marketing Research 31: 243-262.

Rossiter JR, Percy L. 1997. Advertising Communications and Promotion Management (2nd edn). McGraw-Hill: New York.

Seth A. 1990. Sources of value creation in acquisition: an empirical investigation. Strategic Management Journal 11(6): 431-447.

Shan W, Song Y. 1997. Foreign direct investment and the sourcing of technological advantage: evidence from the biotechnology industry. Journal of International Business Studies 28: 267-284.

Shocker AD, Srivastava RK, Reukert RW. 1994. Challenges and opportunities facing brand management: an introduction to the Special Issue. Journal of Marketing Research 31: 149-158.

Smith JB, Barclay DW. 1997. The effects of organizational differences and trust on the effectiveness of selling partner relationships. Journal of Marketing $\mathbf{6 1}$ : $3-21$.
Srivastava RK, Shervani TA, Fahey L. 1998. Marketbased assets and shareholder value: a framework for analysis. Journal of Marketing 62: 2-18.

Teece DJ. 1982. Toward an economic theory of the multiproduct firm. Journal of Economic Behavior and Organization 3: 39-63.

Teece DJ. 1986. Profiting from technological innovation: implications for integration, collaboration, licensing, and public policy. Research Policy 15: 285-305.

Teece DJ. 1987. Technological change and the nature of the firm. In The Competitive Challenge, Teece DJ (ed.). Harper Row: New York; 256-281.

Tsurumi Y. 1976. The Japanese Are Coming: A Multinational Spread of Japanese Firms. Ballinger: Cambridge, MA.

Webster FE. 1992. The changing role of marketing in the corporation. Journal of Marketing 56: 1-17.

Wernerfelt B. 1984. A resource-based view of the firm. Strategic Management Journal 5(2): 171-180.

Wernerfelt B. 1985. Brand loyalty and user skills. Journal of Economic Behavior and Organization 6: 381-385.

Wesson TJ. 1993. An alternative motivation for foreign direct investment. PhD dissertation. Harvard Business School: Boston, MA.

Williamson OE. 1975. Markets and Hierarchies: Analysis and Antitrust Implications. Free Press: New York.

Williamson OE. 1985. The Economic Institutions of Capitalism. Free Press: New York.

Wilson BD. 1980. The propensity of multinational companies to expand through acquisitions. Journal of International Business Studies 11: 59-65.

Yamawaki H. 1991. Exports and foreign distributional activities: evidence on Japanese firms in the United States. Review of Economics and Statistics 73: 294-300.

Yoshida M. 1987. Japanese Direct Manufacturing Investment in the United States. Praeger: New York.

Zaheer S. 1995. Overcoming the liability of foreignness. Academy of Management Journal 38(2): 925-950.

Zahra SA, Ireland RD, Hitt MA. 2000. International expansion by new venture firms: international diversity, mode of market entry, technological learning and performance. Academy of Management Journal 43(5): 925-950. 


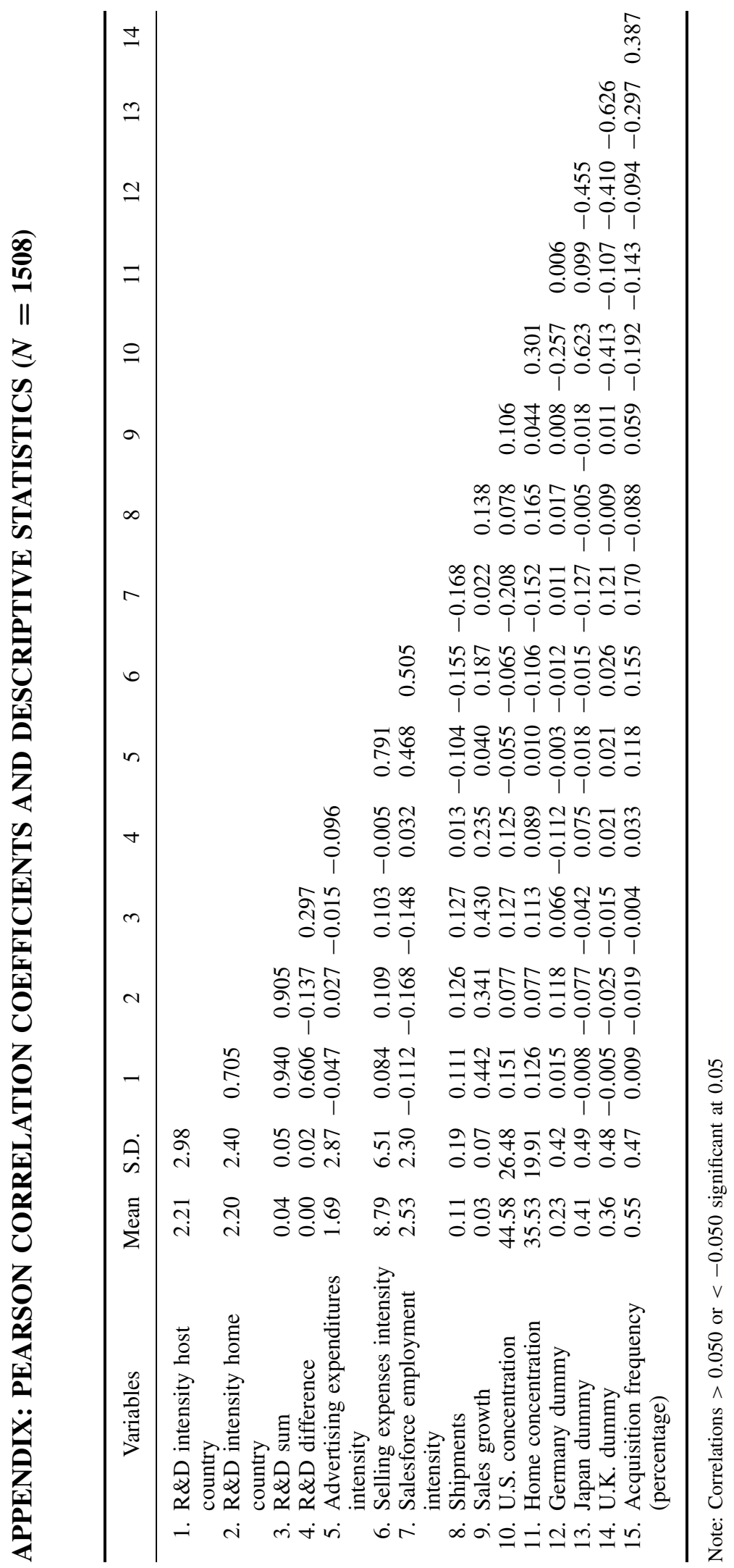

